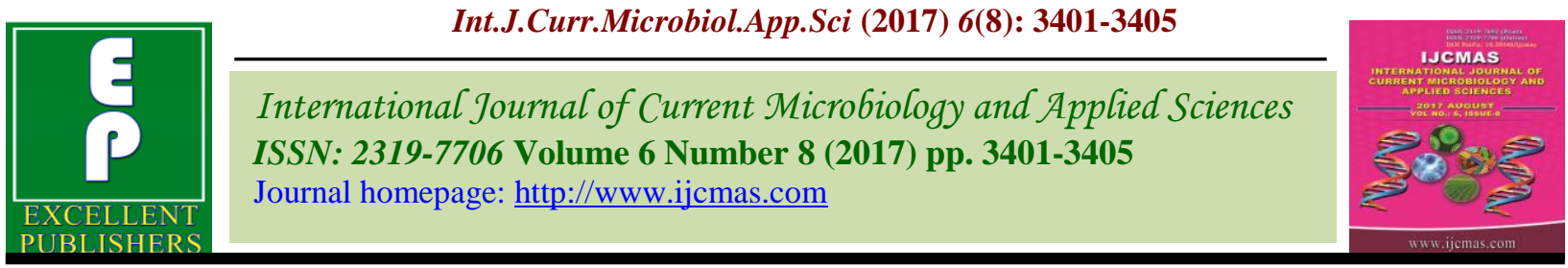

Original Research Article

https://doi.org/10.20546/ijcmas.2017.608.407

\title{
Studies on Proximate Composition of Ragi Based Developed Instant Mixes
}

\author{
Priyanka Goswami*, Mayank Mehra and Parihar Pratibha
}

Department of Food Science and Technology, College of Agriculture, Jawaharlal Nehru Krishi Vishwa Vidyalaya Jabalpur, MP- 482004, India

*Corresponding author

\section{A B S T R A C T}

Keywords

Proximate composition, Ragi, Sorghum, Soybean, Wheat

Article Info

Accepted: 27 June 2017 Available Online: 10 August 2017
The present investigations were carried out in the Department of Food Science and Technology, JNKVV, College of Agriculture, Jabalpur (M.P.) during the year 2015-16. Ragi has enormous health benefits and also a good source of valuable micro nutrients along with the major food components. The highest amount of protein, fiber and fat exhibited by $\mathrm{C} 4$ formulated halwa mix (ragi, wheat, sorghum and soybean at the ratio in 70:10:10:10). The highest amount of protein, fiber and fat exhibited by sprouted ragi, greengram and kutki at the ratio in 60:15:25 in W3 formulated weaning food mix. Ragi formulated chikky was found rich in nutrients and its overall acceptability was also good.

\section{Introduction}

Ragi or finger millet (Eleusine coracana L.) is important millet grown extensively in various regions of India and Africa, constitutes as a staple food for a large segment of the population in these countries (Majumder et al., 2006). It ranks sixth in production after wheat, rice, maize, sorghum and bajra in India. The major ragi growing states are Karnataka, Tamil Nadu, Andhra Pradesh, Orissa, Jharkhand, Maharashtra and Uttaranchal. Nutritionally, its importance is well recognized because of its high content of calcium $(0.38 \%)$, dietary fiber $(18 \%)$ and phenolic compounds $(0.3-3 \%)$. The iodine content is said to be highest among all the food grains. Ragi has best quality protein along with the presence of essential amino acids, vitamin $\mathrm{A}$, vitamin $\mathrm{B}$ and phosphorus (Gopalan et al., 2004). Thus ragi is a good source of diet for growing children, expecting women's, old age people and patients. Ragi is considered to be ideal food for diabetic individuals also due to its low sugar content and slow release of glucose/sugar in the body (Kang et al., 2008 and Lakshmi and Sumathi, 2002). Ragi has considerable versatility and could be used for the preparation of traditional and contemporary food. Halwa refers to many types of dense, sweet confections. It is a type of dessert with the consistency of a very thick. It is generally prepared from various raw materials like fine soji (semolina) from wheat, mung dhal, chick pea. Moreover, the halwa is normally rich in fat and sugar, but not satisfactory in other nutrients. In practice, halwa is sold in the market as ready to eat (RTE), but a ready to prepare (RTP) halwa mix or ready to cook 
(RTC) halwa mix is rather scanty. The daily diet of man must contain adequate amount of protein minerals, vitamins and necessary carbohydrates to supply energy. Wheat and wheat products supply most of the nutrients. Wheat flour contains all the essential amino acid except lysine and tryptophan, vitamins and minerals. The most popular in western countries is bread, biscuits, cake, cookies rolls, pies, doughnuts, pastries, pudding etc. In India, 70 per cent of wheat produced is utilized as chapati and bread, Maida, rawa etc. The cereals or pulses alone or mix based product are generally inferior in nutritional quality. Therefore it was thought to develop a nutritious mixer for development of various traditional products which have more superior quality.

\section{Materials and Methods}

\section{Food commodities}

Ragi, wheat, sorghum, soybean, kutki, and green gram were from the local market Adhartal, Jabalpur.

\section{Statistical analysis}

The results/data of the analysis for different parameters were analyzed statistically to assess the degree of variation within the treatments as compared to the control. The data were subject to analysis of variance (ANOVA) and least significance difference to determine the difference between means, analyzed by Genstat computer package using Completely Randomized Design (CRD) at 5\% level of significant.

\section{Results and Discussion}

\section{Protein}

As data showed in tables 1 to 3 ; the protein content of ragi based halwa mix was decreased as increased level of ragi this may be due to low protein content of ragi than other flours. Protein content increased with incorporation of malted ragi and sprouted greengram. Tables 1 to 3 showed that the maximum protein content was found in W3, (ragi, kutki and greengram) nutritious weaning food, whereas minimum value found in W0 control weaning food. Different combination of nutritive weaning food supplemented with $60 \%$ malted ragi, $25 \%$ sprouted greengram were significantly superior than other formulated weaning food. The similar findings of protein content were also observed by Keshirsagar et al., (1994) and Ashturkar et al., (1992).

The protein content of ragi grains was decrease after puffing processing. This may be due to degradation of protein during heat process. This result supported by Shukla et al., (1986). Protein content of puffed amaranth is more than unpuffed amaranth grains.

\section{Fat}

The fat content of halwa mix was increased due to high fat content of soybean incorporated in mix. This result is close agreement with Curley (2008) in oat porridge. As data showed in tables 1 to 3; the fat content decreased as increased level of ragi malt in weaning food this might be due to low fat content of ragi and greengram. Fat content of puffed grains contains low fat content than compared to unpuffed grains. This result supported by Shukla et al., (1986).

\section{Ash}

The data from tables 1 to 3 revealed that the ash content of halwa mix was increased significantly. Ash content of weaning food increased as increased level of ragi and greengram, this may be due to high ash content present in greengram. This result supported by Kulkarni and Naik (2000). Data 
from tables 1 to 3 reveals that the ash content of puffed grains increases after puffing process.

\section{Carbohydrates}

An appraisal form table the carbohydrate of ragi based halwa mix was decreased as increased level of ragi (Sulochana et al.,
2011). Carbohydrate content of weaning food mixes increases after malting of grains this lead to increased carbohydrate content of weaning food. This result supported by the findings of Mahgoub (1999) in weaning food formulation. Carbohydrate content of puffed ragi more than unpuffed ragi, but carbohydrate content of unpuffed amaranth was more than puffed amaranth grains.

Table.1 proximate composition of Ragi based developed Halwa mixes

\begin{tabular}{|l|l|l|l|l|l|l|l|}
\hline \multirow{2}{*}{ Treatments } & \multicolumn{9}{|l|}{ Proximate composition $(\%)$} \\
\cline { 2 - 8 } & Protein & Fat & Ash & Carbohydrates & Fiber & Minerals & Energy (kcal) \\
\hline Control & 10.68 & 2.60 & 1.6 & 69.4 & 1.9 & 2.7 & 341 \\
\hline C1 & 12.30 & 4.52 & 1.6 & 67.4 & 1.3 & 1.7 & 349 \\
\hline C2 & 12.50 & 4.66 & 1.7 & 65.1 & 1.7 & 1.9 & 339 \\
\hline C3 & 11.10 & 4.06 & 1.8 & 65.3 & 1.9 & 2.0 & 338 \\
\hline C4 & 12.00 & 4.86 & 1.0 & 70.6 & 2.0 & 2.1 & 336 \\
\hline CD at 5\% & 0.25 & 0.11 & 0.1 & 0.3 & 0.1 & 0.2 & 0.55 \\
\hline SE $(m) \pm$ & 0.79 & 0.34 & 0.5 & 1.0 & 0.4 & 0.5 & 1.76 \\
\hline
\end{tabular}

Table.2 Different composition of Ragi based developed weaning food mixes

\begin{tabular}{|l|l|l|l|l|l|l|l|}
\hline \multirow{2}{*}{ Treatments } & \multicolumn{9}{|l|}{ Proximate composition (\%) } \\
\cline { 2 - 8 } & Protein & Fat & Ash & Carbohydrates & Fiber & Minerals & Energy (kcal) \\
\hline Control & 7.60 & 1.14 & 1.93 & 76.18 & 3.80 & 5.81 & 359 \\
\hline C1 & 12.80 & 2.11 & 2.67 & 60.22 & 4.82 & 4.12 & 306 \\
\hline C2 & 11.91 & 1.87 & 2.49 & 62.87 & 4.57 & 3.99 & 315 \\
\hline C3 & 11.03 & 1.64 & 2.31 & 65.55 & 4.32 & 3.85 & 325 \\
\hline C4 & 10.14 & 1.41 & 2.12 & 68.21 & 4.07 & 5.34 & 324 \\
\hline CD at 5\% & 0.09 & 0.10 & 0.08 & 0.25 & 0.50 & 0.10 & 0.21 \\
\hline SE $(m) \pm$ & 0.30 & 0.30 & 0.27 & 0.36 & 0.15 & 0.30 & 0.61 \\
\hline
\end{tabular}

Table.3 Proximate composition of puffed and unpuffed grains

\begin{tabular}{|l|l|l|l|l|}
\hline Parameter & Ragi grain & Puffed ragi & Amaranth grain & Puffed amaranth \\
\hline Moisture $(\%)$ & 13.1 & 8.9 & 10.0 & 6.8 \\
\hline Protein $(\mathrm{g})$ & 7.3 & 6.6 & 14.7 & 15.9 \\
\hline Fat $(\mathrm{g})$ & 1.3 & 1.2 & 1.9 & 5.9 \\
\hline Total carbohydrate $(\mathrm{g})$ & 72.0 & 78.0 & 60.7 & 59.0 \\
\hline Crude fibre $(\mathrm{g})$ & 3.6 & 3.5 & 9.6 & 5.5 \\
\hline Ash $(\mathrm{g})$ & 2.7 & 2.8 & 2.0 & 2.9 \\
\hline Energy value (Kcal) & 328.0 & 329.0 & 319.0 & 371.0 \\
\hline Mineral $(\mathrm{g})$ & 2.7 & 2.8 & 3.1 & 4.0 \\
\hline
\end{tabular}




\section{Fiber}

The tables 1 to 3 showed that the fiber content was increased with increasing the ratio of supplementation of ragi in composite flour to prepare halwa. Maximum fiber content was found in $\mathrm{C} 4$ whereas minimum was found in Control halwa mix. These findings might be due to incorporation of ragi which is rich source of fiber (Poongadi and Mohankumar, 2009). The fiber content was found to be increased with increase in millet flour blend level in composite flour. Fiber content in weaning food increases as increased level of ragi due to high fiber content of ragi. Fiber content of puffed grains were increased after heat process.

\section{Mineral}

As data from tables 1 to 3 ; the minerals content of halwa mix was increased as increased level of ragi this might be due to more minerals content present in ragi. Minerals content of weaning food increases as increased level of ragi malt. This may be due to high minerals content in ragi Minerals content of grains increased after puffing process.

\section{Energy}

An appraisal forms tables 1 to 3; the energy value of halwa mix decreased as increased level of ragi. This might be due to decreased level of protein and fat content in halwa mixes. The result showed in tables 1 to 3 ; the energy value of weaning food increases significantly. This result supported by Ashtukar et al., (1992). As data from tables 1 to 3 ; the energy value of puffed grains were more than compared to unpuffed grains.

The work can be concluded from the above results that ragi based halwa and weaning food were found nutritionally superior in terms of protein, fiber, ash and mineral contents. Ragi based chikky was an attempt made to prepare chikky from puffed ragi and amaranth grains, it was also good acceptable in the ratio of 40 puffed ragi, 30 puffed amaranth and 30 jaggery. These products can be exploited for commercial venture because of their high nutritional quality. It was suggested that ragi being the cheapest source of calcium, may be used to prepare common daily food stuffs to increase its nutritional value, acceptability and palatability of products. Development and consumption of such value added products will help in increasing the utilization of all millets and economic upliftment hence will contribute for health of the population.

\section{Acknowledgement}

The authors are thankful to the Dean, College of Agriculture, Jawaharlal Nehru Krishi Vishwa Vidyalaya Jabalpur for providing necessary facilities and permission to conduct the study.

\section{References}

Ashturkar, P.B., Pande, V. and Reddy, S. 1992. Development and evaluation of weaning food formulation. J. Fd. Sci. and Technology; 23(3): 197-198.

Curley, J.P., 2008. Sensory and nutritional evaluation of soy porridge. Int. J. Nitri.; 19: 41-50.

Gopalan, C., Ramasastri, B.V. and Balasubramanian, S.C. 2004. Nutritive value of Indian Foods; National Institute of Nutrition (NIN). Indian Council of Medical Research, Hyderabad; pp: 59-67.

Kang, R.K., Jain, R. and Mridula, D. 2008. Impact of indigenous fiber rich premix supplementation on blood glucose levels in diabetics. Am. J. Food Tech.; 3(1): 50-55. 
Kaushik, G., Satya, S. and Naik, S.K. 2010. Effect of domestic processing techniques on the nutritional quality of the soybean. Mediterranean journal of nutrition and metabolism; 3(1): 39-46.

Keshirsagar, R.B., Pawar, V.D., Upadhyay, V.P., Pawar, V.S. and Devi, R. 1994. Studies on formulation and evaluation of a weaning food based on locally available foods. $J . \quad F d$. Sci. and Technology; 31(3): 211-214.

Lakshmi, K.P., and Sumathi, S. 2002. Effect of consumption of finger millet on hyperglycemia in non-insulin dependent diabetes mellitus (NIDDM) subjects. Food Nutr. Bull.; 23(3): 241-245.

Majumder, T.K., Premavalli, K.S. and Bawa, A.S. 2006. Effect of puffing on calcium and iron contents of ragivarieties and their utilization. J. Food Sci. Tech.; 42(5): 542-545.

Poongadi Vijayakumar, T., and Mohankumar, Jemima Beryl 2009. Formulation and characterization of millet flour blend incorporation composite flour. International Journal of Agri. Science; 1: 46-54.

Shukla, S.S., Gupta, O.P. and Sharma, Y.K. 1986. Puffing quality of characteristics of some ragi (Elusine coracana) cultivars. Journal of Food Science and Technology; 23: 329-330.

Sulochana, S., and Bakiyalakshmi, S.V. 2011. Effect of Neutraceutical Dosa on Antimicrobial Activity. International Journal of Environmental Sciences; 1(5): 0976-4402.

\section{How to cite this article:}

Priyanka Goswami, Mayank Mehra and Parihar Pratibha. 2017. Studies on Proximate Composition of Ragi Based Developed Instant Mixes. Int.J.Curr.Microbiol.App.Sci. 6(8): 3401-3405. doi: https://doi.org/10.20546/ijcmas.2017.608.407 